\title{
Performance evaluation of mutual funds in India with special reference to selected financial intermediaries
}

\author{
${ }^{1}$ Mohamed.zaheeruddin, ${ }^{2}$ Pinninti Sivakumar, ${ }^{3}$ K.Srinivas Reddy \\ ${ }^{I}$ MCom, MBA (Gold Medal), (PhD), Associate Professor DRK Institute of science and technology Hyderabad, \\ Experience 9 years of in Teaching. \\ ${ }^{2}$ MCom, MBA, (MPhill), Associate Professor DRK College of Engg. And Technology Hyderabad, Experience 12 \\ years of in teaching. \\ ${ }^{3}$ MSc (MPhill)Associate Professor DRK Institute of science and technology Hyderabad, Experience 15 years of \\ in Teaching.
}

\begin{abstract}
Mutual Fund companies are financial intermediaries providing financial services to small investors through mobilisation of funds, when the investors invest in a mutual fund they are buying shares or units of the mutual fund and become a shareholder of the fund. Mutual funds are one of the best investments ever created because they are very cost efficient and very easy to invest in. Thus the Rupee is generated in the form of big returns to promote financial excellence.

The financial reforms and cut throat competition in the economic environment the mutual fund industry has opened new vistas to interested investors and imparted much needed liquidity to the Indian financial system. In a jungle evolution of financial service sector in India investors are unable to recognise and select the benchmarking companies. The study examines the performance of mutual funds based on their fund return, risk and performance ratios.
\end{abstract}

Keywords Small investors, Big Returns, Net Asset Value, Beta, Alpha, Financial Excellence, Financial Assets, Asset classes.

\section{Introduction}

A Mutual fund is a trust that pools the savings of a number of investors who share a common investment objective. The income of investor is collected and invested by the fund manager in various types of Asset classes. These include 1. Stocks 2. Debt instruments 3. Short term Money Market Instruments and other securities depending on the objectives of the scheme, which in turn gives Little Savings to its unit holders in proportion of the number of unit $s$ they own.

There are many types of mutual funds like equity funds, bond funds, balanced funds, growth funds, income funds, tax saving funds, country funds, index funds, exchange traded funds, sector funds etc.

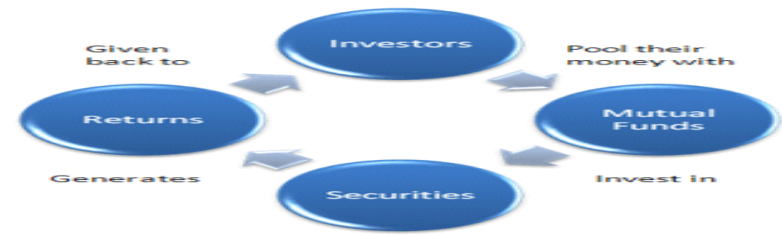

Fig.1 The flow chart describes broadly the working of mutual funds.

\subsection{Features of Mutual Funds}

- Investors purchase standard units of fixed value at the inception of a fund.

- Most funds also offer investors opportunity to enter after inception at prevailing value of the units.

- Each fund has its own investment objective.

- Depending on the objective, the investment avenues targeted by each fund will be different.

- Investors chose between various funds based on their own personal investment objectives.

- Funds are managed by professional fund managers for a fees.

- The value of a unit at any given point would depend upon the value of the various investments made by the fund at that point in time.

- Subject to conditions stated at the time of inception of the fund. The investors can redeem their investments as and when they want.

1.2 Constituents of mutual fund's

All mutual funds comprise of four constituents 
1. Sponsors

2. Trust /Board of trustees

3. Asset management company or fund managers

4. Custodian

There are many entities involved and the diagram below illustrates the organizational set up of a mutual funds

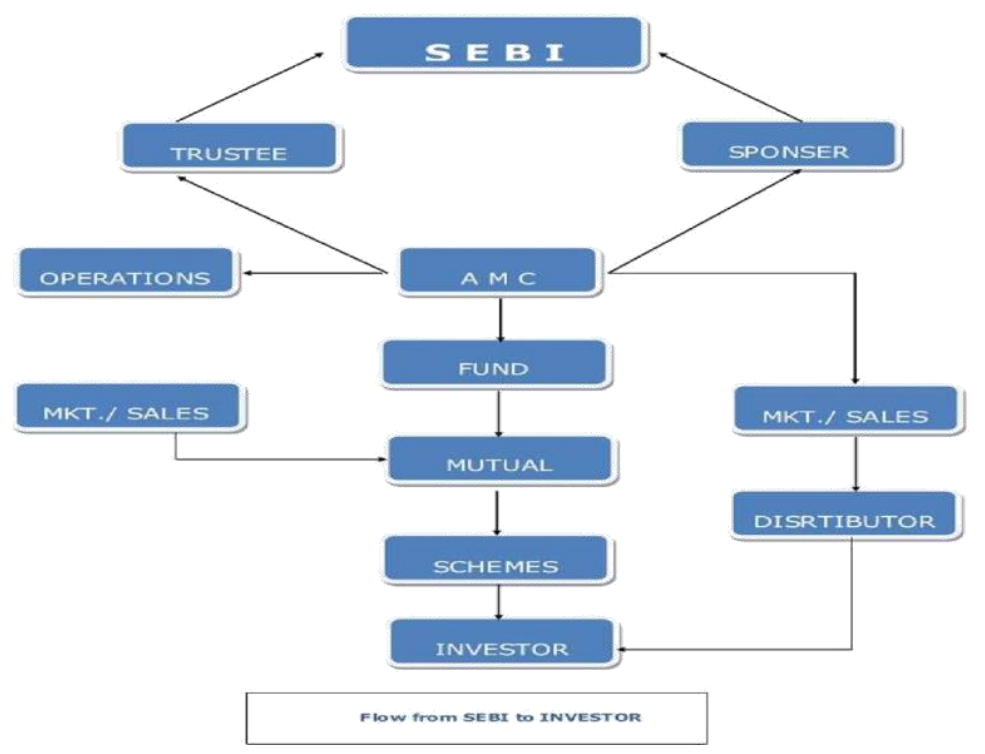

Fig.2 Structure of mutual funds

\subsection{Net Asset Value (NAV) The concept}

The NAV is nothing but the market price of a particular scheme in relation to all the assets of a scheme. It can otherwise be called the intrinsic value of each unit. The value is the true indicator of the performance of the fund.

If NAV > Face value of the unit, it indicates that the money invested on that unit has appreciated.

\subsection{Mutual funds in India}

- Monopoly by Unit Trust of India

- Entry of Commercial Banks.

- Launch of variety of schemes

- Tie up arrangements with foreign collaborators

- Entry of Private Sector Preferred as an avenue of investment.

\section{Review of literature}

Sharpe (1966) suggested a measure for the evaluation of portfolio performance. Drawing on results obtained in the field of portfolio analysis. Economist Jack L Treynor suggested a new predictor of mutual fund performance, one that differs from virtually all those used previously by incorporating the volatility of a funds return in a simple yet meaningful manner. Jensen (1967) derived a risk adjusted measure of portfolio performance (Jensen alpha) that estimates how much a manager's forecasting ability contributes to a fund's returns.

Ippolito (1989) finds that there is no significant relationship between performance, after expenses turnover and investment fees.

Wermers (2000) demonstrates a positive relationship between performance and turnover and suggest that the funds engaged in more active trading may be found underpriced securities.

Navdeep Aggarwal and Mohit Gupta, ICFAI Journal of finance 2007, No.9, Vol.13, "performance of Mutual funds in india an empirical study" The study was conducted using CAPM and FAMA French model and concluded that the value addition of the fund depends on certain factors such as excess market returns, size factor, value factor and suggest that returns earned by Mutual funds were actually due to the exposure of these factors only and fund managers did not add any value.

Soumya Guha Deb Icfai University Press 2008 Vol.14 No.8 "performance of Indian equity Mutual funds Vis-a-Vis their style benchmarks" has suggested that in her evaluation of fund managers performance 
found that Indian equity fund managers have not been able to beat their style benchmarks (William Sharpe ratio) on the average and pointed out the weaknesses of fund managers.

Ravi vyas and suresh Chandra moonat (2012) Indian Journal of Finance, Vol. 6 No. 8, "Perception and behaviour of Mutual Funds Investors in Madhya Pradesh" concluded that the highly volatile funds are risky and therefore the fund manager should collect all possible information before making an investment. A careful and reasonable diversification of investment in mutual funds should be done on the investor's part to balance the risk involved in investment. And suggested that investors should inculcate the habit of saving regularly so, that the little savings will grow into a big returns.

J.S. Yadav and O.S. Yadav (2012) Indian Journal of Finance, Vol. 6 No. 9, "The Indian Stock Market :A Comparative Study of Mutual Funds and Foreign Institutional Investors" in their analysis of comparison between Mutual Funds and Foreign Institutional Investors, it was found that though the India is an attractive destination for investment by Foreign Institutional Investors, investments made by the mutual funds were greater than investment made by FII's, during the recession MF industry has played a vital role in pushing the economy upward while FII's withdrew their investment, showing the importance of MF's in Indian economy.

\section{Objectives of the study}

1. To investigate the financial performance of the mutual funds with the tools of return, standard deviation and beta.

2. To evaluate the selected funds assessment on the basis of various performance ratios (Sharpe, Treynor, Jensen)

3. To compare HDFC, Birla sun life and ICICI equity performance with the S\&P CNX Nifty Index, to give rankings of mutual funds by their outstanding performance.

\section{Research methodology}

\subsection{Sample size}

Three Financial intermediaries were considered from financial services sector to analyse the performance evaluation of Mutual funds of the companies, the name of the companies were given below.

1. HDFC Mutual funds

2. Birla Sun Life Mutual funds

3. ICICI Mutual funds

\subsection{Sampling tools}

\section{TABLE.1: SAMPLING TOOLS USED FOR ANALYSIS}

\begin{tabular}{|c|c|}
\hline Calculation of Return & $(P 1-P 0 / P 0) 100$ \\
\hline Standard deviation & $\sqrt{D^{2} / N}$ \\
\hline$\beta$ (Beta value) & covariance/ $/ m \times \sigma m$ \\
\hline Sharpe's ratio & $(R m-R f) / \sigma$ \\
\hline Treynor's ratio & $(R m-R f) / \beta$ \\
\hline
\end{tabular}

\section{Hypothesis}

5.1 $\mathrm{H}_{\mathbf{0}}$ (Null Hypothesis): The performance evaluation of funds using the performance ratios improves performance of companies and enables the investors to recognise and select the benchmarking companies.

5.2 $\mathrm{H}_{1}$ (Alternative Hypothesis): The performance evaluation of funds using the performance ratios does not improve performance of companies and the investors are unable to recognise and select the benchmarking companies. 


\section{Analysis of selected mutual funds based on Return (R), Standard Deviation ( $\sigma$ ) and Beta (B)}

Table.2 Calculation of Average Quarterly Returns and Risks, covariance of HDFC \& S\&P CNX Nifty funds

\begin{tabular}{|c|c|c|c|c|c|c|c|c|c|}
\hline $\mathrm{Dd} / \mathrm{mm} / \mathrm{yx}$ & $\begin{array}{c}\text { NAV } \\
\text { (HDFC) }\end{array}$ & $\mathbf{R}$ & D & $\begin{array}{c}\mathrm{D}^{2} \text { (HDFC } \\
\text { Risk) }\end{array}$ & $\begin{array}{c}\text { NAV } \\
\text { (S\&P) }\end{array}$ & $\mathbf{R}$ & D & $\begin{array}{c}d^{2} \text { (Market } \\
\text { Risk) }\end{array}$ & $\begin{array}{c}\mathrm{D}_{\mathrm{A}}^{\wedge} \mathrm{d}= \\
\mathrm{Coy}\end{array}$ \\
\hline 01-Jul-09 & 10.87 & - & - & - & 4340.9 & - & - & - & - \\
\hline 01-Oct-09 & 13.05 & 20.05 & 16.09 & 258.88 & 5083.4 & 17.1 & 14.8 & 219.04 & 238.13 \\
\hline 04-Jan-10 & 14.18 & 8.65 & 4.69 & 21.99 & 5232.2 & 2.92 & 0.62 & 0.38 & 2.9 \\
\hline 01-Apr-10 & 14.22 & 0.28 & -3.68 & 13.54 & 5290.5 & 1.11 & -1.19 & 1.41 & 4.37 \\
\hline 01-Jul-10 & 15.13 & 6.39 & 2.43 & 5.9 & 5251.4 & -0.73 & -3.03 & 9.18 & -7.36 \\
\hline $01-$ Oct-10 & 17.47 & 15.46 & 11.5 & 132.25 & 6143.4 & 16.98 & 14.68 & 215.5 & 168.82 \\
\hline 03-Jan-11 & 17.32 & -0.85 & -4.81 & 23.13 & 6157.6 & 0.23 & -2.07 & 4.28 & 9.95 \\
\hline 01-Apr-11 & 16.65 & -3.86 & -7.82 & 61.15 & 5826.05 & -5.38 & -7.68 & 58.98 & 60.05 \\
\hline 01-Jul-11 & 16.56 & -0.54 & -4.5 & 20.25 & 5627.2 & -3.41 & -5.71 & 32.6 & 25.69 \\
\hline 03 -Oct-11 & 14.59 & -11.8 & -15.8 & 251.2 & 4849.5 & -13.8 & -16.1 & 259.85 & 255.5 \\
\hline $02-\mathrm{Jan}-12$ & 13.34 & -8.56 & -12.5 & 156.75 & 4636.75 & -4.38 & -6.68 & 44.62 & 83.63 \\
\hline 02-Apr-12 & 15.81 & 18.51 & 14.55 & 211.7 & 5317.9 & 14.69 & 12.39 & 153.51 & 180.27 \\
\hline Total & & 43.64 & & 1156.76 & & 25.31 & & 999.35 & 1021.95 \\
\hline
\end{tabular}

Source: Monthly Returns \& Nav's Of S\&P Cnx Index And Hdfc Are From Amfi And Nse (Computed On Quarterly Basis).

Calculation Of Various Sampling Tools

Calculation of HDFC Return

Calculation of S\&P CNX Nifty Return

Calculation of HDFC's (S.D) Risk

Calculation of S\&P Nifty's (S.D) Risk

Calculation of Covariance

Calculation of (B) Beta value

$$
\begin{aligned}
& =R=\sum R / N=43.64 / 11=3.96 \\
= & M R=\sum R / N=25.31 / 11=2.3 \\
= & \sqrt{ } D^{2} / N=\sqrt{ } 1156.79 / 11=10.25 \\
= & \sqrt{ } M D^{2} / N=\sqrt{ } 999.38 / 11=9.53 \\
= & \text { Avg. } \text { covariance }=1021.99 / 11=92.90 \\
= & \text { covariance } / \sigma m \times \sigma m \\
= & 92.90 /(9.53 \times 9.53)=1.02
\end{aligned}
$$

$R \boldsymbol{m}$ calculated on Quarterly returns.

$R_{f}=10$ taken as annual rate of interest, hence convert it into Quarterly, 10/4 $=\mathbf{2 . 5}$

Calculation of Sharpe's ratio

Calculation of Treynor's ratio

$=(R m-R f) / \sigma=(3.96-2.5) / 10.25=1.46 / 10=0.14$

Calculation of Jenson's Alpha

$$
\begin{gathered}
=(R m-R f) / \beta=(3.96-2.5) / 1.02=1.43 \\
=(R-R m) \quad=3.96-2.3=1.66
\end{gathered}
$$

Table 3. Calculation of Average Quarterly Returns and Risks, covariance of Birla Sun Life \& S\&P CNX Nifty

\begin{tabular}{|c|c|c|c|c|c|c|c|c|c|}
\hline $\mathbf{D d} / \mathbf{m m} / \mathbf{y y}$ & $\begin{array}{c}\text { NAV } \\
\text { (BSL) }\end{array}$ & $\mathbf{R}$ & $\mathbf{D}$ & $\begin{array}{c}\mathbf{D}^{2} \text { (HDFC } \\
\text { Risk) }\end{array}$ & $\begin{array}{c}\text { NAV } \\
\text { (S\&P) }\end{array}$ & $\mathbf{R}$ & $\mathbf{D}$ & $\begin{array}{c}\mathbf{d}^{2} \text { (Market } \\
\mathbf{R i s k})\end{array}$ & $\begin{array}{c}\mathbf{D}^{\wedge} \mathbf{d}= \\
\mathbf{C o v}\end{array}$ \\
\hline 01-Ju1-09 & 13.4 & - & - & - & 4340.9 & - & - & - & - \\
\hline 01-Oct-09 & 15.73 & 17.38 & 15.92 & 253.44 & 5083.4 & 17.1 & 14.8 & 219.04 & 235.61 \\
\hline 04-Jan-10 & 16.77 & 6.61 & 5.15 & 26.52 & 5232.2 & 2.92 & 0.62 & 0.38 & 3.19 \\
\hline 01-Apr-10 & 17.01 & 1.43 & -0.03 & 0.0009 & 5290.5 & 1.11 & -1.19 & 1.41 & 0.035 \\
\hline 01-Ju1-10 & 17.03 & 0.11 & -1.35 & 1.82 & 5251.4 & -0.73 & -3.03 & 9.18 & 4.09 \\
\hline 01-Oct-10 & 19.29 & 13.27 & 11.81 & 139.47 & 6143.4 & 16.98 & 14.68 & 215.5 & 173.37 \\
\hline 03-Jan-11 & 18.38 & -4.71 & -6.17 & 38.06 & 6157.6 & 0.23 & -2.07 & 4.28 & 12.77 \\
\hline 01-Apr-11 & 16.53 & -10.0 & -11.5 & 132.71 & 5826.05 & -5.38 & -7.68 & 58.98 & 88.47 \\
\hline 01-Ju1-11 & 15.89 & -3.87 & -5.33 & 28.4 & 5627.2 & -3.41 & -5.71 & 32.6 & 30.43 \\
\hline 03-Oct-11 & 14.04 & -11.6 & -13.1 & 171.61 & 4849.5 & -13.8 & -16.1 & 259.85 & 211.17 \\
\hline 02-Jan-12 & 11.87 & -15.4 & -16.9 & 285.94 & 4636.75 & -4.38 & -6.68 & 44.62 & 112.95 \\
\hline 02-Apr-12 & 14.6 & 22.99 & 21.53 & 463.54 & 5317.9 & 14.69 & 12.39 & 153.51 & 266.75 \\
\hline Total & & 16.06 & & 1541.51 & & 25.31 & & 999.35 & 1138.83 \\
\hline
\end{tabular}

SOURCE: Monthly Returns \& Nav's Of S\&P Cnx Index And Birla Sun Life Are From Amfi And Nse (Computed On Quarterly Basis).

\section{Calculation of Various Sampling Tools}

Calculation of Birla Sun Life's Return

Calculation of S\&P CNX Nifty's Return

Calculation of Birla Sun Life's (S.D) Risk

Calculation of S\&P CNX Nifty's (S.D) Risk

Calculation of Covariance

Calculation of ( $(3)$ Beta value

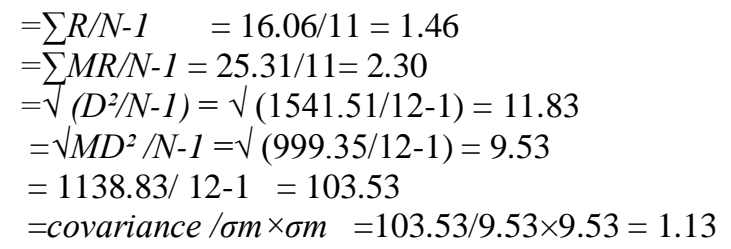


NOTE: Rm calculated on Quarterly returns.

$R_{f}=10$ taken as annual rate of interest, hence convert it into Quarterly, 10/4 $=2.5$

Calculation of Sharpe's ratio

Calculation of Treynor's ratio

$$
\begin{aligned}
& =(R m-R f) / \sigma=(1.46-2.5) / 11.83=-0.08 \\
& =(R m-R f) / \beta \quad=(1.46-2.5) / 1.13=-0.92 \\
& =(R-R m) \quad=1.46-2.30=-0.84
\end{aligned}
$$

Table.4 Calculation of Average Quarterly Returns and Risk, covariance of ICICI \& S\&P CNX Nifty

\begin{tabular}{|c|c|c|c|c|c|c|c|c|c|}
\hline Dd/mm/yy & $\begin{array}{c}\text { NAV } \\
\text { (ICICI) }\end{array}$ & $\mathbf{R}$ & $\mathbf{D}$ & $\begin{array}{c}\mathbf{D}^{\mathbf{2}} \text { (HDFC } \\
\text { Risk) }\end{array}$ & $\begin{array}{c}\text { NAV } \\
\text { (S\&P) }\end{array}$ & $\mathbf{R}$ & $\mathbf{D}$ & $\begin{array}{c}\mathbf{d}^{\mathbf{2}} \text { (Market } \\
\text { Risk) }\end{array}$ & $\begin{array}{c}\mathbf{D}^{\wedge} \mathbf{d}= \\
\text { Cov }\end{array}$ \\
\hline 01-Jul-09 & 10.9 & - & & - & 4340.9 & - & - & - & - \\
\hline 01-Oct-09 & 13.05 & 19.72 & 15.59 & 243.04 & 5083.4 & 17.1 & 14.8 & 219.04 & 230.73 \\
\hline 04-Jan-10 & 13.73 & 5.21 & 1.08 & 1.16 & 5232.2 & 2.92 & 0.62 & 0.38 & 0.66 \\
\hline 01-Apr-10 & 14.29 & 4.07 & -0.06 & 0.0036 & 5290.5 & 1.11 & -1.19 & 1.41 & 0.07 \\
\hline 01-Jul-10 & 14.57 & 1.95 & -2.18 & 4.75 & 5251.4 & -0.73 & -3.03 & 9.18 & 6.6 \\
\hline 01-Oct-10 & 17.17 & 17.84 & 13.71 & 187.96 & 6143.4 & 16.98 & 14.68 & 215.5 & 201.26 \\
\hline 03-Jan-11 & 17.38 & 1.22 & -2.91 & 8.46 & 6157.6 & 0.23 & -2.07 & 4.28 & 6.02 \\
\hline 01-Apr-11 & 16.85 & -3.04 & -7.17 & 51.4 & 5826.05 & -5.38 & -7.68 & 58.98 & 55.06 \\
\hline 01-Jul-11 & 16.68 & -1 & -5.13 & 26.31 & 5627.2 & -3.41 & -5.71 & 32.6 & 29.29 \\
\hline 03-Oct-11 & 14.87 & -10.8 & -14.9 & 224.4 & 4849.5 & -13.8 & -16.1 & 259.854 & 241.47 \\
\hline 02-Jan-12 & 14.46 & -2.75 & -6.88 & 47.33 & 4636.75 & -4.38 & -6.68 & 44.62 & 45.95 \\
\hline 02-Apr-12 & 16.35 & 13.07 & 8.94 & 79.92 & 5317.9 & 14.69 & 12.39 & 153.51 & 110.76 \\
\hline Total & & 45.44 & & 874.73 & & 25.31 & & 999.35 & 927.87
\end{tabular}

SOURCE: Monthly Returns \& Nav's Of S\&P Cnx Index And Icici Are From Amfi And Nse (Computed On Quarterly Basis).

\section{CALCULATION OF VARIOUS SAMPLING TOOLS}

Calculation of ICICI's Return

Calculation of S\&P CNX Nifty's Return

Calculation of ICICI (S.D) Risk

Calculation of S\&P CNX Nifty's (S.D) Risk

Calculation of covariance

Calculation of (ß) Beta value $=\sum R / N-1 \quad=45.44 / 11=4.13$

$=\sum M R / N-1=25.31 / 11=2.30$

$=\sqrt{ }\left(D^{2} / N-1\right)=\sqrt{ }(874.73 / 12-1)=8.91$

$=\sqrt{ } M D^{2} / N-1=\sqrt{ }(999.35 / 12-1)=9.53$

$=927.87 / 12-1=84.35$

$=$ covariance $/ \sigma m \times \sigma m=84.35 / 9.53 \times 9.53=0.92$

NOTE: Rm calculated on Quarterly returns.

$R_{f}=10$ taken as annual rate of interest, hence convert it into Quarterly, $10 / 4=2.5$

Calculation of Sharpe's ratio

Calculation of Treynor's ratio

Calculation of Jenson's Alpha

$$
\begin{aligned}
& =(R m-R f) / \sigma=(4.13-2.5) / 8.91=0.18 \\
& =(R m-R f) / \beta=(4.13-2.5) / 0.92=1.77 \\
& =(R-R m)=4.13-2.30=1.83
\end{aligned}
$$

Table.5 Analysis of Performance of three funds

\begin{tabular}{|c|l|c|c|c|c|c|c|}
\hline $\begin{array}{c}\text { Sr. } \\
\text { No }\end{array}$ & \multicolumn{1}{|c|}{ Name of Funds } & $\begin{array}{c}\text { Avg. } \\
\text { Return }\end{array}$ & $\begin{array}{c}\text { Risk } \\
\text { (S.D) }\end{array}$ & Beta & $\begin{array}{c}\text { Sharpe's } \\
\text { Ratio }\end{array}$ & $\begin{array}{c}\text { Treynor's } \\
\text { Ratio }\end{array}$ & $\begin{array}{c}\text { Jenson's } \\
\text { Alfa }\end{array}$ \\
\hline 1 & HDFC Long term equity fund & 3.96 & 10.25 & 1.02 & 0.14 & 1.43 & 1.66 \\
\hline 2 & Birla Sun Life mutual fund & 1.46 & 11.83 & 1.13 & -0.08 & -0.92 & -0.84 \\
\hline 3 & $\begin{array}{l}\text { ICICI Focused Blue chip } \\
\text { equity fund }\end{array}$ & 4.13 & 8.91 & 0.92 & 0.18 & 1.77 & 1.83 \\
\hline
\end{tabular}


Fig.3: Analysis of Performance of 3 Funds Based on Return, Risk \& Beta

Fig.4: Analysis of Performance evaluation based on Sharpe, Treynor \& Jenson
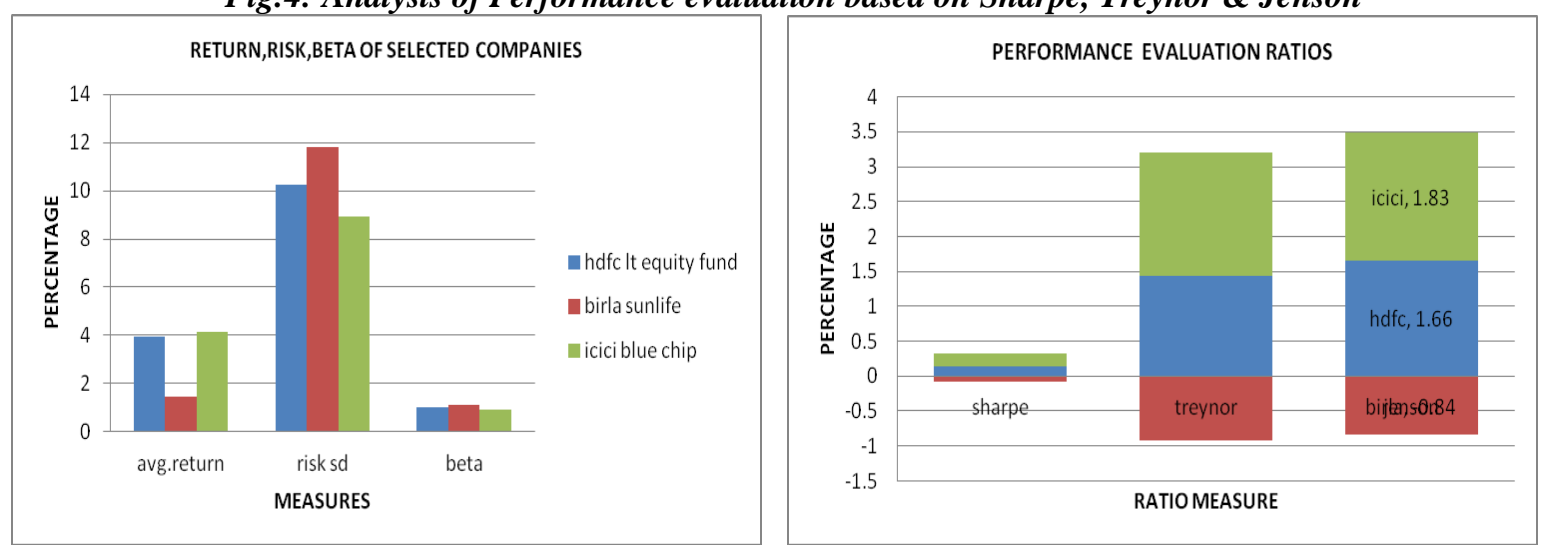

INTERPRETATION: From the above comparative analysis it is observed that ICICI equity fund indicates high returns $(R)$ among the selected funds. When compared to companies' risk $(\sigma)$ and the market risk $(\beta)$ Birla sun life mutual fund has higher risk and ICICI has low risk.

As per the performance ratios of 3 companies ICICI's performance is better when compared to selected funds.

Table.6 ranking of funds according to 3 performance ratios

\begin{tabular}{|c|c|c|c|c|c|}
\hline Rank & Sharpe & Rank & Treynor & Rank & Jenson \\
\hline 1 & ICICI & 1 & ICICI & 1 & ICICI \\
\hline 2 & HDFC & 2 & HDFC & 2 & HDFC \\
\hline 3 & Birla Sun Life & 3 & Birla Sun Life & 3 & Birla Sun Life \\
\hline
\end{tabular}

INTERPRETATION: Out of the selected financial intermediaries, the interested investor can invest in ICICI mutual fund as it is ranked in the top position as per the performance ratios.

\section{Conclusion}

The Mutual funds are one of the best investment source available for Indian small investors to make an investment, if thoroughly assessed it may give big returns with little savings. The above performance ratios are very much helpful for the evaluator to assess the fund's performance. As the Mutual Fund investment is subject to market conditions, therefore for the risk averse investors there are so many other investment alternatives available apart from the mutual funds, such as investment in other Financial Assets (stock market, debentures, Bonds, Treasury bills etc) and other Non Financial Assets (post office certificates, Bank deposits, Pension schemes, Real estate's) to avoid risk.

\section{References}

[1] Agarwal N.P. Mishra B. K. Sonia Agarwal,(2007) “Issues in Financial Management”, RBSA Publishers, $1{ }^{\text {st }}$ edition.

[2] Bollen N P B and Busse J A (2004) “short-term persistence in Mutual Fund Performance”, Review of Financial studies, Vol.18, No.2,PP.569-597

[3] Cai J, Chan K C and Yamada (1997) “The Performance of Japanese Mutual Funds”, The Review of Financial Studies Vol.10, No.2, PP.237-273

[4] Chang, E., and W. Levellen, “Market Timing and Mutual Fund Investment Performance”, Journal of Business (January 1984)

[5] Donald E. Fischer, Ronald J. Jordon "Security Analysis and Portfolio Management", 6 th edition, PHI.

[6] Gangadhar V. and Ramesh Babu G., "Investment Management", Anmol Publications Pvt. Limited.

[7] Gupta Shivani (2011) “Indian Mutual Fund Industry: Current state and Future outlook” Indian Journal of Finance, Vol.5, Issue 4, PP.38

[8] J.S. Yadav and O.S. Yadav (2012), “The Indian Stock Market :A Comparative Study of Mutual Funds and Foreign Institutional Investors" Indian Journal of Finance, Vol. 6 No. 9.

[9] Jaydev M. (1996) “Mutual Funds Performance, An Analysis of Monthly Returns”, Finance India,Vol.10, Issue 1, PP.73-84

[10] Navdeep Aggarwal and Mohit Gupta, , "performance of Mutual funds in india an empirical study" ICFAI Journal of finance 2007, No.9, Vol.13

[11] Otten R and Bams D (2002) “European Mutual Fund Performance”, European Financial Management, Vol.8, No.1,PP.75-101

[12] Pandey I M. “Financial management”, (Jan.2005), Vikas Pulishing House Pvt. Ltd., $9^{\text {th }}$ edition.

[13] Prasanna Chandra "Investment Analysis and Portfolio Management", CFM-TMH Professional Series in Finance, $2^{\text {nd }}$ edition.

[14] Ravi vyas and suresh Chandra moonat (2012), "Perception and behaviour of Mutual Funds Investors in Madhya Pradesh" Indian Journal of Finance, Vol. 6 No. 8.

[15] Richard A Brealey Stewart C Myers Franklin Allen, Pitabas Mohanty “Principles of Corporate Finance”, $8^{\text {th }}$ edition, Tata Mc Graw-Hill Publishing Company Limited. 
[16] Sharpe W. F. (1996) “Mutual Fund Performance”. Journal of Business, Vol.34, Issue 2, PP. 119-138.

[17] Soumya Guha Deb "performance of Indian equity Mutual funds Vis-a-Vis their style benchmarks" Icfai University Press 2008 Vol.14 No.8

[18] The Performance of Mutual Funds in the Period 1945-1964, Journal of Finance ( May 1968) PP. $389-416$

[19] Yasaswy. N.J. "Finance Profits, Guide for non-financial managers" (Feb. 2006) Vision books $2^{\text {nd }}$ edition,

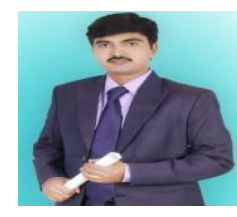

Mr. Mohamed Zaheeruddin 1* received his degree of M.Com with a specialization in Accounting from Osmania University, Hyderabad, and MBA finance from Dr.BRAO University, Hyderabad. Later to excel and to cope up with the industry requirements pursued MBA with Marketing also from JawaharLal Nehru Technological University and achieved a GOLD MEDAL for academic excellence. Pursuing Ph.D from Rayalaseema University, Kurnool, and A.P. in the area of Management. Have 3 publications and 4 paper presentations in various national and international journals. And has overall 9 years of teaching experience. Presently working as Associate Professor at DRK institute of science and technology, Hyderabad. His main research interest include investment analysis, mutual funds, price level analysis (inflation), Derivatives and other related areas of management.

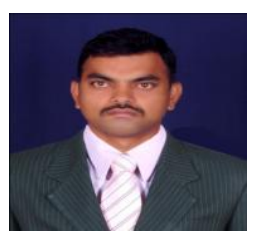

Mr. Pinninti.Sivakumar 2** pursued M.Com with a specialization in Accounting and MBA finance from Osmania University, Hyderabad. Presently pursuing M.Phil (commerce) from M.K.University, Chennai. in the area of Management. Has 1 publication, and has overall 12 years of teaching experience. Presently working as a Associate Professor at DRK College of engineering and technology, Hyderabad. His area of interest is stock market analysis, Commodities \& Derivatives.

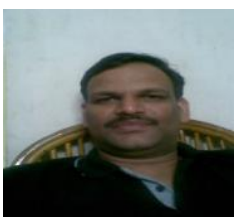

Mr.K.Srinivas Reddy $3^{* * *}$ pursued MSc statistics with a specialization in quality control and operations research from Nagarjuna University, A.P. Presently pursuing M.Phil from. Nagarjuna University, A.P. And has overall 15 years of teaching experience. Presently working as a Associate Professor at DRK institute of science and technology, Hyderabad. 